\title{
Escapement success and patterns of downstream migration of female silver eel Anguilla anguilla in the River Meuse
}

\author{
Hilde Verbiest ${ }^{1}$, André Breukelaar ${ }^{2}$, Michaël Ovidio ${ }^{3}$, Jean-Claude Philippart ${ }^{3}$, Claude Belpaire ${ }^{1}$ \\ ${ }^{1}$ Research Institute for Nature and Forest, Hoeilaart, Belgium \\ ${ }^{2}$ Rijkswaterstaat Waterdienst, Lelystad, The Netherlands \\ ${ }^{3}$ University of Liège, Biology of Behaviour Unit, Laboratory of Fish Demography and Hydroecology, Tihange, Belgium
}

Accepted for publication February 6, 2012

\begin{abstract}
Downstream migration of female silver eel Anguilla anguilla (L.) was studied by remote telemetry in the lower part of the River Meuse (Belgium and the Netherlands) using a combination of nine detection stations and manual tracking. $N=31$ eels $\left(L_{\mathrm{T}} 64-90 \mathrm{~cm}\right)$ were implanted with active transponders and released in 2007 into the River Berwijn, a small Belgian tributary of the River Meuse, $326 \mathrm{~km}$ from the North Sea. From August 2007 till April 2008, 13 eels (42\%) started their downstream migration and were detected at two or more stations. Mean migration speed was $0.62 \mathrm{~m} \cdot \mathrm{s}^{-1}$ (or $53 \mathrm{~km} \cdot \mathrm{day}^{-1}$ ). Only two eels $(15 \%)$ arrived at the North Sea, the others being held up or killed at hydroelectric power stations, caught by fishermen or by predators or stopped their migration and settled in the river delta. A majority $(58 \%)$ of the eels classified as potential migrants did not start their migration and settled in the River Berwijn or upper Meuse as verified by additional manual tracking.
\end{abstract}

Key words: Anguilla anguilla; silver eel; downstream migration; telemetry; River Meuse

\section{Introduction}

The stock of the European eel, Anguilla anguilla (L.), has declined since 1980, most likely due to a variety of reasons such as climate and oceanic changes, pollution, fisheries, presence of migration barriers, habitat loss, diseases and predation (Feunteun 2002; Knights 2003; Dekker 2004; Durif et al. 2006; Geeraerts \& Belpaire 2010). While the relative impact of each cause remains unclear, several international management measures aiming to restore the stock have recently been taken. European measures (EU, 2007) focus on a maximal restoration of the silver eel escapement, to allow sufficient eels to start their journey to their spawning place at the Sargasso Sea. However, fisheries managers and researchers are faced with methodological bottlenecks when quantifying current silver eel escapement in their eel management unit. Practical problems related to the nocturnal and poorly known nature of the silver eel run for the time being difficult to predict, complicate quantifications, especially in large rivers. While accurate estimates of the total silver eel biomass leaving a catchment are seldom achievable, researchers make use of the growing performance of tagging and tracking systems developed for fish. The use of state-of-the-art tagging and tracking technologies permits to follow individual eels along their migration route (e.g., Jansen et al. 2007; Aarestrup et al. 2009, 2010; Davidsen et al. 2011). This has opened possibilities to gain new insights on the biological nature of the migration, including a better understanding of the environmental factors regulating this migration. Moreover, application of these new techniques may facilitate the quantification of the impact of anthropogenic and other pressures on the migrating silver eels. Mapping the bottlenecks along eel's migration route is critical for deciding on the appropriate management measures 


\section{Verbiest et al.}

aiming to achieve the internationally concerted objective for silver eel escapement [ $40 \%$ silver eel biomass relative to the best estimate of escapement that would have existed if no anthropogenic influences had impacted the stock (EU, 2007)].

Although significant knowledge has been presented on the migration of the silver eel in rivers [e.g., in the Imsa (Vøllestad et al. 1986) and the Rhine (Breukelaar et al. 2009)], in coastal areas in Denmark (Aarestrup et al. 2010) and Norway (Davidsen et al. 2011) and in the ocean (Tesch 1974; Aarestrup et al. 2009), many aspects are still not well understood. Moreover, migratory behaviour is dependent on local environmental conditions and pressures.

By making use of the new technical opportunities in tagging and tracking, this study aims to evaluate the environmental factors associated with the triggering of the downstream migration and to describe the movement patterns, the speed and the escapement success of individual female silver eels equipped with transponders in an impacted large west European river, the River Meuse.

\section{Materials and methods}

\section{Study area}

The River Meuse has a total length of $925 \mathrm{~km}$ from its source in France to the North Sea. The river basin covers a catchment area of about $36,000 \mathrm{~km}^{2}$, of which $26 \%$ is in France, $2 \%$ in Luxemburg, $39 \%$ in Belgium, $11 \%$ in Germany and $22 \%$ in the Netherlands. The Meuse is fed by rainwater, whereby the discharge can fluctuate widely. Mean water discharge $(1998-2007)$ is $223.2 \mathrm{~m}^{3} \cdot \mathrm{s}^{-1}$ at Visé, close to the Belgian-Dutch border (Data from SETHY). The lower reach of the River Meuse from the Belgian-Dutch border to the estuary can be divided into a nonimpounded part (the transboundary Meuse) and an impounded part downstream of Maasbracht. Several migration obstructions such as dams, weirs and hydropower stations (HPS) are located on the River Meuse. The impounded part of the river includes seven weirs and two HPS (at Linne and Lith) (Fig. 1), each weir equipped with a fish pass. In the Meuse delta, a network of tributaries offers different migration routes. The rivers Meuse and Rhine share the Haringvliet as their former estuary.

Eels equipped with transponders were released in the River Berwijn and followed during their downstream migration along the R. Meuse. R. Berwijn is a tributary of the R. Meuse in Belgium, located at $326 \mathrm{~km}$ from the sea. The river has a total length of $31.9 \mathrm{~km}$ from its source in Aubel to its mouth in the R. Meuse and has a drainage area of about $128 \mathrm{~km}^{2}$. Mean discharge is $1.32 \mathrm{~m}^{3} \cdot \mathrm{s}^{-1}$ (HIC, 2009).

\section{Eel capture, tagging and telemetry}

The method used to follow eel migration was based on telemetry with the NEDAP TRAIL ${ }^{\circledR}$ System. Silver eels with implanted transponders were tracked by remote telemetry at nine fixed detection locations distributed along the Meuse (Breukelaar et al. 2009). Eels were caught by electrofishing or by fykenetting between June and December 2007 at different locations in Belgium: River Berwijn, River Meuse, Canal Bocholt-Herentals and Canal Brussel-Charleroi (Fig. 1). Female silver eels were selected using external characteristics (total length $L_{\mathrm{T}}$, body weight $W$, horizontal $\mathrm{ED}_{\mathrm{H}}$ and vertical eye diameter $\mathrm{ED}_{\mathrm{V}}$, pectoral fin length $L_{\mathrm{PF}}$ ) to determine their maturation stage according to Durif et al. (2005) (Table 1). On this basis, 31 silver eels classified as potential migrants (SF-III; $n=11$ ) and migrants (SF-IV \& SF-V; $n=20$ ) were selected. $L_{\mathrm{T}}$ ranged from $643 \mathrm{~mm}$ to $896 \mathrm{~mm}$ (mean $\pm \mathrm{SD}=761 \pm 135 \mathrm{~mm}$ ) and $W$ from 491 to $1487 \mathrm{~g}$ (mean $\pm \mathrm{SD}=884 \pm 604 \mathrm{~g}$ ). These eels were transferred to the INBO laboratory for tagging. Prior to surgery, eels were anaesthetized using a $0.1 \mathrm{ml} \cdot 1^{-1}$ solution of clove oil. The transponders were surgically implanted in the posterior quarter of the body cavity through a 30-mm-long mid-ventral incision. The transponders (NEDAP TRAIL $^{\circledR}$; length: $65 \mathrm{~mm}$; diameter: $15 \mathrm{~mm}$; weight in air: $26.5 \mathrm{~g}$; life span: 2 years) consist of an inert glass capsule, containing a transmitter, a receiver and a small battery (Breukelaar et al. 1998). Transponders weight represents maximum $5.4 \%$ of the body weight of the eel. Eels with transponders fitted that were caught by fisherman can be reported, as the transponders are marked with a name and telephone number. All eels recovered well after surgery and after recovery eels were kept in a 1000-1 water tank. One to five days after tagging, they were released in the R. Berwijn about $3 \mathrm{~km}$ from the river mouth (Fig. 1). Tagged eels were released on June 5th $(n=6)$, October 17th $(n=12)$ and 26th $(n=7)$, and November 14th $(n=4)$ and 23rd $(n=2)$, 2007. Morphometrical description of the eels from these batches is given in Table 2.

The detection system used was the NEDAP TRAIL $^{\circledR}$ System. Each detection system consists of three parallel antenna cables installed in the cross section on the bottom of the river linking both river banks. The antenna is connected to a transmitter receiver detection station that registers the individual unique code and time of passing of fish equipped with the transponders.

In the Netherlands, a network of more than 50 of these detection stations registers large-scale movements of migratory fish in Rhine and Meuse. Eight locations in the Meuse (at constructions such as weirs, fish passes and HPSs) are equipped with detection 


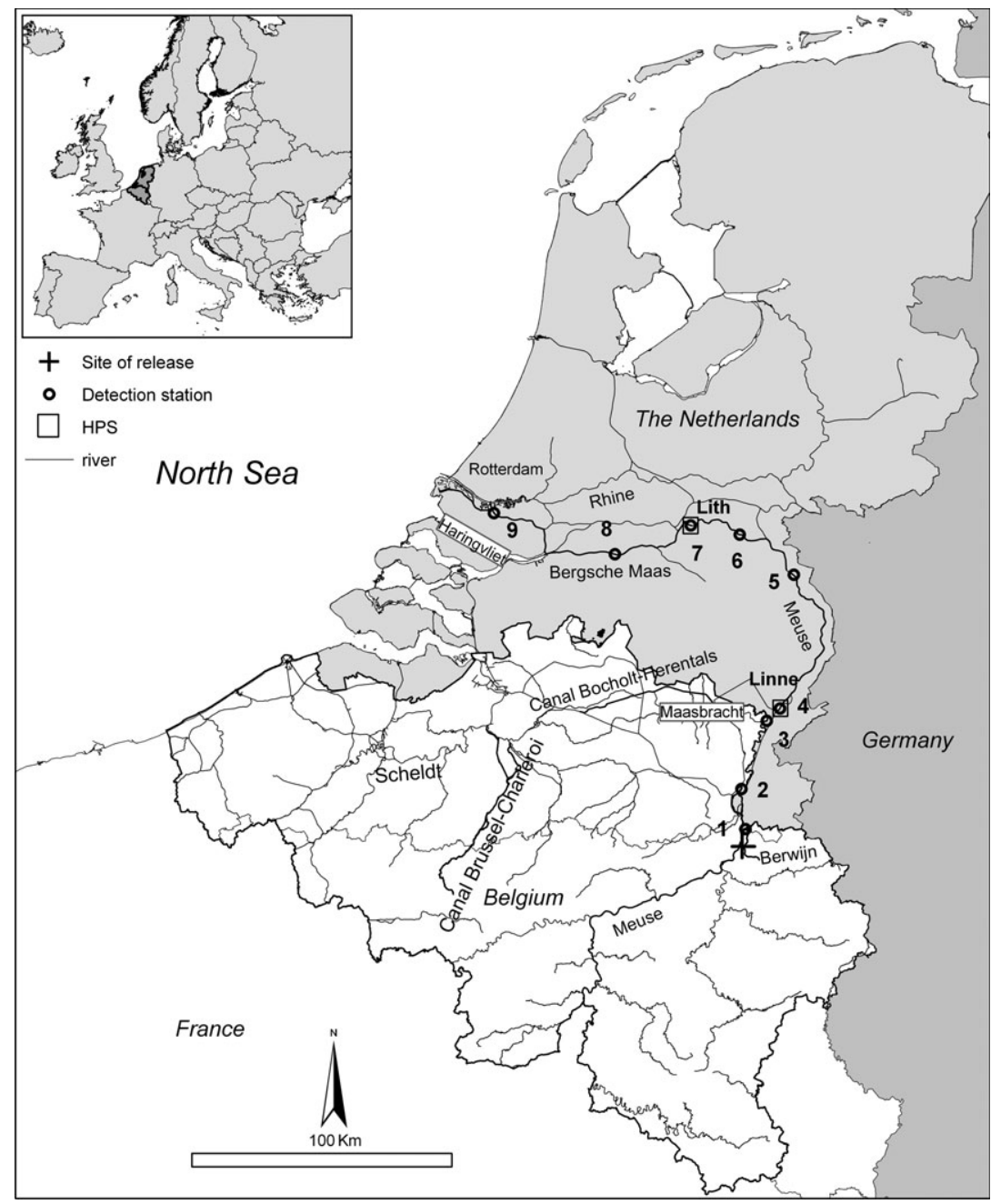

Fig. 1. Map of the study area with the locations of the site of release (+) and the detection stations (O) in the River Meuse and the River Berwijn (Station: $1=$ River Berwijn, 2-7 = River Meuse, 8-9 = River Meuse delta) and the hydropower stations ( $\square$ ) in the River Meuse.

Table 1. Distribution of maturation stages (following Durif et al. 2005) with number of individuals $(n)$ in the eels equipped with transponders and relevant morphological parameters [total length $\left(L_{T}\right)$, body weight $(W)$, horizontal eye diameter $\left(E D_{H}\right)$, vertical eye diameter $\left(E D_{V}\right)$ and pectoral fin length $\left.\left(L_{P F}\right)\right]$. Means and standard deviation are indicated.

\begin{tabular}{|c|c|c|c|c|c|c|}
\hline $\begin{array}{l}\text { Maturation } \\
\text { index }\end{array}$ & $n$ & $\begin{array}{l}L_{T} \\
(\mathrm{~mm})\end{array}$ & $W(\mathrm{~g})$ & $\begin{array}{l}\mathrm{ED}_{\mathrm{H}} \\
(\mathrm{mm})\end{array}$ & $\begin{array}{l}\mathrm{ED}_{\mathrm{V}} \\
(\mathrm{mm})\end{array}$ & $\begin{array}{l}L_{\mathrm{PF}} \\
(\mathrm{mm})\end{array}$ \\
\hline SF-III & 11 & $740 \pm 69$ & $778 \pm 259$ & $9.0 \pm 0.6$ & $8.5 \pm 0.5$ & $34.1 \pm 1.6$ \\
\hline SF-IV & 11 & $795 \pm 57$ & $1138 \pm 246$ & $9.5 \pm 0.6$ & $9.1 \pm 0.7$ & $38.2 \pm 4.3$ \\
\hline SF-V & 9 & $743 \pm 61$ & $701 \pm 256$ & $10.0 \pm 0.6$ & $9.2 \pm 0.8$ & $37.0 \pm 3.7$ \\
\hline
\end{tabular}

stations. One station is located in Belgium on the River Berwijn 500 m upstream its mouth in the River Meuse (Fig. 1).

On five occasions between November 2007 and April 2008, additional manual tracking of eels with transponders was carried out in the River Berwijn. For this, we used a portable Nedap TRAIL detection device, consisting of a portable antenna connected to a portable transmitter receiver (detection range: $10 \mathrm{~m}$ ).

\section{Results and discussion}

In general, transition in maturity stages from II to IV occurs at the end of the summer (Durif et al. 2005). However, in this study, female eels in the pre silver SF-III and migrant stage SF-IV can be found in River Berwijn as early as the start of June. It cannot be excluded that those eels were individuals that did not migrate during the 2006-2007 season and regressed to a resident stage.

From August 2007 till April 2008, 22 of the 31 (71\%) silver eels with implanted transponders passed at least one detection station (Station 1; Fig. 1). Thirteen of the eels $(42 \%)$ passed Stations 1 and 2 situated respectively at a distance of 2.5 and $22 \mathrm{~km}$ from the point of release. These 13 eels were assumed to have started their downstream migration towards the North Sea (Table 3).

Our data suggest that in the River Meuse, in general, an increase in water discharge triggers eel 


\section{Verbiest et al.}

Table 2. Number $(n)$, total length $\left(L_{T}\right)$, body weight $(M)$, maturation index (following Durif et al. 2005) and date of release (DR) of the eels in four batches of eels from different origin and the proportion of migrants (Mig) after release. Means, standard deviation, minimum and maximum are indicated.

\begin{tabular}{|c|c|c|c|c|c|c|c|c|}
\hline \multirow[b]{2}{*}{ Origin } & \multirow[b]{2}{*}{ DR } & \multirow[b]{2}{*}{$n$} & \multirow[b]{2}{*}{$L_{\mathrm{T}}(\mathrm{mm})$} & \multirow[b]{2}{*}{$W(\mathrm{~g})$} & \multicolumn{3}{|c|}{ Maturation index } & \multirow[b]{2}{*}{ Mig $(\%$} \\
\hline & & & & & SF-III & SF-IV & SF-V & \\
\hline River Berwijn & 5 June 2007 & 6 & $773 \pm 71(643-834)$ & $1053 \pm 176(867-1308)$ & 1 & 5 & 0 & 33 \\
\hline Canal Bocholt-Herentals & 17 October 2007 & 12 & $753 \pm 67(657-896)$ & $794 \pm 277(491-1198)$ & 3 & 3 & 6 & 58 \\
\hline Canal Brussel-Charleroi & 26 October 2007 & 7 & $761 \pm 69(660-874)$ & $911 \pm 294(667-1487)$ & 2 & 2 & 3 & 29 \\
\hline River Meuse & $\begin{array}{l}14 \text { and } 23 \\
\text { November } 2007\end{array}$ & 6 & $763 \pm 38(724-814)$ & $861 \pm 72(775-944)$ & 5 & 1 & 0 & 33 \\
\hline
\end{tabular}

Table 3. Migration success and migration speed of tagged downstream migrating female silver eels released at River Berwijn and detected at detection stations along the River Meuse (numbers as shown in Fig. 1).

\begin{tabular}{|c|c|c|c|c|c|c|c|c|}
\hline $\begin{array}{l}\text { Station } \\
\text { number }\end{array}$ & River & $\begin{array}{l}\text { Location of } \\
\text { detection stations }\end{array}$ & $D_{\text {SEA }}(\mathrm{km})$ & $D_{\mathrm{DS}}(\mathrm{km})$ & $N_{\text {PAS }}$ & $N_{\text {DET }}$ & $\begin{array}{l}\text { Migration } \\
\text { speed }\left(\mathrm{m} \cdot \mathrm{s}^{-1}\right)\end{array}$ & $\begin{array}{l}\text { Migration speed } \\
\left(\mathrm{km} \cdot \text { day }^{-1}\right)\end{array}$ \\
\hline $1 \dagger$ & Berwijn & Moelingen & 323.0 & $3.0 \%$ & 22 & 21 & & \\
\hline 2 & Meuse & Itteren & 303.5 & 19.5 & 13 & 12 & $0.19 \pm 0.32(0.01-0.87)$ & $16.5 \pm 28.0(0.7-75.5)$ \\
\hline 3 & Meuse & Stevensweert & 261.8 & 41.7 & 9 & 6 & $0.37 \pm 0.50(0.01-1.33)$ & $31.9 \pm 43.5(0.8-115.0)$ \\
\hline 4 & Meuse & Linne HPS & 253.5 & 8.3 & 9 & 7 & $0.33 \pm 0.49(0.00-1.33)$ & $28.5 \pm 42.2(0.3-115.1)$ \\
\hline 5 & Meuse & Sambeek & 177.0 & 76.5 & 8 & 6 & $0.69 \pm 0.61(0.23-1.88)$ & $59.5 \pm 52.9(20.0-162.1)$ \\
\hline 6 & Meuse & Balgoij & 147.5 & 29.5 & 8 & 8 & $1.13 \pm 0.66(0.29-1.93)$ & $97.9 \pm 57.3(25.2-166.6)$ \\
\hline 7 & Meuse & Lith HPS & 123.5 & 24.0 & 8 & 8 & $0.82 \pm 0.62(0.01-1.50)$ & $70.8 \pm 53.2(0.8-130.0)$ \\
\hline 8 & Meuse & Bergsche Maas & 84.0 & 39.5 & 8 & 8 & $0.91 \pm 0.54(0.11-1.39)$ & $78.3 \pm 46.7(9.2-120.5)$ \\
\hline 9 & Meuse & $\begin{array}{l}\text { Oude Maas } \\
\text { Spijkenisse }\end{array}$ & 14.0 & 70.0 & 2 & 2 & $0.70 \pm 0.04(0.67-0.73)$ & $60.5 \pm 3.4(58.1-62.9)$ \\
\hline Total & & & & & & & $0.62 \pm 0.59(0.00-1.93)$ & $53.4 \pm 51.4(0.3-166.6)$ \\
\hline
\end{tabular}

HPS, hydropower station; $D_{\text {SEA }}$, distance from the sea; $D_{\mathrm{DS}}$, distance between two consecutive detection stations; $N_{\text {PAS }}$, number of eels passing the detection station with or without detection; $N_{\mathrm{DET}}$, number of eels detected at the detection station.

Calculations of migration speed are based on the time interval between detections of individual eels at two consecutive detection stations. Means, standard deviation, minimum and maximum are indicated.

†Migration speed of eels in the River Berwijn (between detection station 1 and 2) is not calculated, because of the unknown delay of departure after release. †istance between site of release and Station 1 .

migration (Fig. 2). This is in line with reports by Lowe (1952), Vøllestad et al. (1986) and Durif \& Elie (2008). Eel migration and water discharge both peaked early December, although some individuals started to migrate during a peak of increased water flow at the end of August. Nevertheless, some individuals seem to start migration in periods with no, or very low, increase in water discharge. Locomotory activity in silver eels may also be triggered by other factors such as atmospheric depression (Okamura et al. 2002) or changes in water composition (rise in turbidity, decrease of conductivity; Durif et al. 2008). As depicted in Fig. 2, the peak of water discharge in River Meuse during the first half of December is associated with a decrease in both turbidity and conductivity, probably as a result of dilution.

From the 13 eels that started their migration, five ceased migration, were caught by fishermen or died for another reason between Station 2 and 5. Eight continued their migration towards the Meuse delta via the Bergsche Maas (Station 8). Two individual eels of this group were able to reach the North Sea via the Oude Maas and the harbour of Rotterdam, completing their $326 \mathrm{~km}$ migration in 35 and 97 days. These eels were detected at all nine detection stations in the River Meuse and Berwijn. The other six eels were detected at Station 1 till Station 8, but not at Station 9, alternative routes to the sea are not available without being noticed through other detection stations (not indicated in Fig. 1). These eels are presumed having failed reaching the North Sea. It is not known whether these eels were caught by fishermen (although no transponders were reported by fisherman), died for other reasons (e.g., predation) or stopped their migration and settled in the river delta. Most probably, fishing pressure in the Meuse delta has the largest impact, although factual information on the catches is lacking. Also other reports (Dekker 2000; Winter et al. 2006; Jansen et al. 2007) suggested eel fisheries in the River Meuse as an important mortality factor during silver eel migration. Aarestrup et al. (2010) estimated that also in Denmark eel mortality is large in the early phase of the marine migration and that fishing may be a major cause of mortality of migrating silver eels. An increasing number of reports (e.g., Acou et al. 2009; Belpaire et al. 2009; Geeraerts et al. 2011) suggest that migration success might be jeopardized by a decreased fitness of the silver eels starting their 

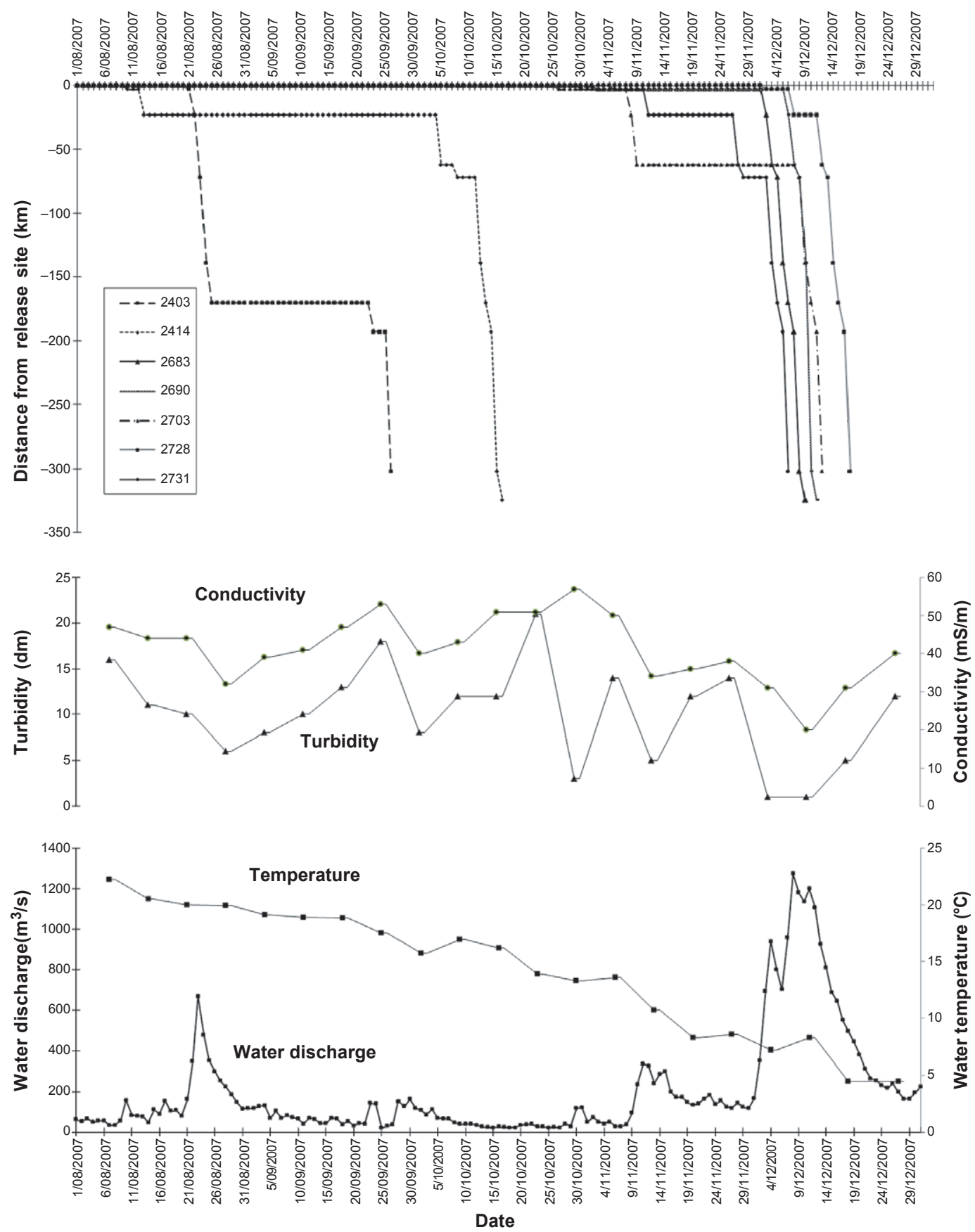

Fig. 2. Migration pattern of seven downstream migrating female silver eels after release in relation to water discharge of the River Meuse at Maaseik (HIC, 2009) and water conditions (conductivity, turbidity and water temperature) at Eijsden in 2007 (Waterbase, Rijkswaterstaat, the Netherlands). Individual eel numbers are indicated.

journey to the spawning area. Lowered condition (e.g., because of high levels of bioaccumulated contaminants and/or the presence of specific pathogens) and associated decreased energy reserves might hamper a successful achievement of their reproductive journey. In particular, this could be the case for silver eels that have grown up in the River Meuse, as it has been shown that yellow eels in this river have considerably lower fat levels compared with eels from other water bodies, questioning their ability as silver eels to reach the spawning area (Belpaire et al. 2009). However, no information is available on the lipid reserves of the eels in our experiment; moreover, it may reasonably be accepted that shortness of energy while migrating will not occur during the initial freshwater part, but during the oceanic part of the migration. Hence, we assume that it is unlikely that eventual differences in eel fitness between the various batches would result in 


\section{Verbiest et al.}

differential migration performance within the lower reach of the river.

From our data, the success of the silver eel migration in the River Meuse is estimated at 15\% (2 of 13 migrating eels reached the North Sea). In 2006, Winter et al. (2006) reported an eel escapement of $37 \%$ from a more downstream reach of the River Meuse to the North Sea, while in the River Rhine, it was estimated at 23\% (in 2004) and $15 \%$ (in 2005) by Klein Breteler et al. (2007), and 38\% (in 2006) were estimated to reach the sea by Breukelaar et al. (2009).

The downstream migration of the silver eels is hindered by two HPSs, at Linne and Lith (Fig. 1). At these sites, three migration routes are possible: through the turbines, through the weir or through the fish pass, which can be individually monitored through the detection systems. All eels used the route via the turbines or the alternative route via the weir, and no tagged eels were registered through the detection system at the fish pass. Five of nine eels were detected in front of one of the HPSs. One eel (at Linne) is presumed to have died as a consequence of passing through the turbines. Data did not reveal eel mortality at Lith HPS. Choosing the route through the turbine caused delays of $18 \mathrm{~h}$ to 1 month, but delays were not seen in eels passing via the weir next to the HPS. Similar delays at HPS were also observed by Durif et al. (2003) and Jansen et al. (2007). Also Winter et al. (2006) found a clear difference in passage behaviour at HPSs, where $40 \%$ showed multiple detections, indicating a hesitation to pass the turbines. At any other detection stations, eels showed no such hesitation behaviour. As discussed by Acou et al. (2008), delayed migration and associated loss in energy might impair migration and breeding success of silver eels. Eels stop feeding once silvering is completed, and sufficient lipid stores are essential to fuel eel migration.

Individual variation in behaviour of migrating silver eel is high. The analysis of detections at the stations demonstrated the existence of different behavioural patterns during downstream migration (Fig. 2). Often migration was interrupted for a few days up to a month and then started up again. Migration speed between two consecutive detection stations varied considerably between individual silver eels (range 0.003$1.93 \mathrm{~m} \cdot \mathrm{s}^{-1}$ ), with an average migration speed of $0.62 \pm 0.59 \mathrm{~m} \cdot \mathrm{s}^{-1}$ (Table 3). The mean migration speed was estimated at $53.4 \pm 51.4 \mathrm{~km} \cdot$ day $^{-1}$ $(n=57)$. For comparison, at this speed, silver eels would reach the Sargasso Sea within 4 months (112 days) if maintaining the progression rates as recorded in the River Meuse. The fastest eel covered a distance of $29.5 \mathrm{~km}$ within $4 \mathrm{~h} 15 \mathrm{~min}\left(1.93 \mathrm{~m} \cdot \mathrm{s}^{-1}\right.$ or $167 \mathrm{~km} \cdot \mathrm{day}^{-1}$ ). In the Baltic, in the absence of river flow, female silver eels showed an average swimming speed of $0.4 \mathrm{~m} \cdot \mathrm{s}^{-1}$ (Westerberg et al. 2006). Aarestrup et al. (2010) reported even slower progression speed of silver eels migrating through a fjord in Denmark $\left(0.046 \mathrm{~m} \cdot \mathrm{s}^{-1}\right)$, while Davidsen et al. (2011) estimated a mean migratory speed of $0.14 \mathrm{~m} \cdot \mathrm{s}^{-1}$ for 26 silver eels in a Norwegian fjord. van den Thillart et al. (2004) recorded a mean swimming speed of $0.39 \mathrm{~m} \cdot \mathrm{s}^{-1}$ for female silver eels $\left(L_{T}=80 \mathrm{~cm}\right)$ in swimming tunnels covering a distance equivalent to $2850 \mathrm{~km}$. Speeds are dependent on a combination of swimming speed and current velocity (Vøllestad et al. 1986; Tesch 2003). The higher mean migration speed in the Meuse eels can probably be attributed to the river current (with a water discharge $>1000 \mathrm{~m}^{3} \cdot \mathrm{s}^{-1}$ during migration peak), but our data are in line with progression rates reported by Tesch (1974) (mean $0.7 \mathrm{~m} \cdot \mathrm{s}^{-1}$ ) and McCleave \& Arnold (1999) (0.35$0.58 \mathrm{~m} \cdot \mathrm{s}^{-1}$ ). From our data, there are no indications that the maturation stage influences migration speed.

This study shows that $42 \%(n=13)$ of the tagged silver eels migrated downstream, but $58 \%(n=18)$ did not leave and at least nine settled in the River Berwijn as was demonstrated through manual tracking. This tracking reveals that the nonmigrants behave as resident after being released in the River Berwijn and apparently found a new home site. No upstream movement was observed, except for return to the home site. Distances between release site and their new home site in the Berwijn varied from 0 to $650 \mathrm{~m}$ (mean $380 \mathrm{~m}$ ). From this supposed home site small daily movements are made. Eels were never registered more than $300 \mathrm{~m}$ from their home site.

Studies on downstream migrating eels are mainly focused on the success of downstream migration in relation to seasonal, meteorological or hydrological parameters (Cullen \& McCarthy 2003; Winter et al. 2006; Jansen et al. 2007; Klein Breteler et al. 2007), not taking into account the nonmigrants. These nonmigrating individuals are often classified as 'lost' or 'delayed migrants'. In the small French River Frémur, around $20 \%$ of the eels identified as silver eels migrated during the following year, while others stayed in the river for an extra year before starting their migration or recovered yellow eel characteristics, but it was assumed that a larger ratio of individuals settled in the river or died (mainly because of antropogenic causes) (Acou et al. 2000; Feunteun et al. 2000). Davidsen et al. (2011) reported from a study of tracked silver eels in a Norwegian fjord that of 32 tagged eels, $6(19 \%)$ were not registered at the detection stations downward the release site. They suggested several possible causes: loss through predation, malfunctioning transmitters or low detection efficiency in the river. This study however shows that nonmigrants are not lost, but simply are not participating in the downstream migration. Taking this 
into account, the telemetry data show an overall escapement of female silver eels in the River Meuse of $15 \%$ (2 of 13 migrants) instead of $6.5 \%$ (2 of 31 migrants and nonmigrants). The nonmigrants do not participate in the downstream migration and thus should not be taken into account in the assessment. Hence, it is essential to estimate the proportion of nonmigrants during silver eel migration studies, especially in the process of implementation of the European Eel Regulation where specific benchmarks for silver eel escapement are defined.

The high proportion of nonmigrants in our eels, which were classified as potential migrants (SF-III) and migrants (SF-IV and SF-V), suggests that classification of migrating silver eels by external characteristics is not a sufficiently accurate predictor of migratory behaviour (Fig. 3). A major question is why more than half of the silver eels did not start their migration and preferred to stay nearby the site of release. It could be argued that these differences in migration behaviour might be linked to tagging effects or to individual differences in maturation stage or even differences in the origin or in time of release of these translocated eels. Transponders weigh on average $3.2 \%$ of the eel's body weight and thus have a higher tag/body mass ratio than the $2 \%$ rule of thumb used by several authors, but considered as inappropriate by others (e.g., Jepsen et al. 2003). Hence, we cannot rule out that transponders may influence behaviour or even health of the eels, however, as our results of telemetry detections indicate, apparently all eels recovered well from tagging and the same transponders have been used successfully in other studies (Breukelaar et al. 1998, 2009; Winter et al. 2006; Jansen et al. 2007; Klein Breteler et al. 2007; De Leeuw \& Winter 2008). The maturation stage (SF-III, SF-IV, SF-V) does not seem to influence the onset of the downstream migration. It would make sense that migration behaviour would be the lowest among the SF-III stages, as these eels are less mature. However, as depicted in Fig. 3, the proportion of nonmigrants is the highest in the SF-V eels.

Also origin of the eels might explain differences in migration behaviour. As in Belgium, intensive restocking of glass eels takes place in many rivers and canals, it is not known whether our eels resulted originally from stocked glass eel (imported from UK or France) or glass eel that recruited naturally. From observations in a Swedish lake, Westin (2003) hypothesized that silver eels stocked as glass eels had had no opportunity to imprint the directional cues necessary for migration and lacked the orientation mechanism necessary to locate the outlet of the lake for starting migration. But Verreault et al. (2010) reported that American eels (Anguilla rostrata) stocked as glass eels can migrate seaward at least as

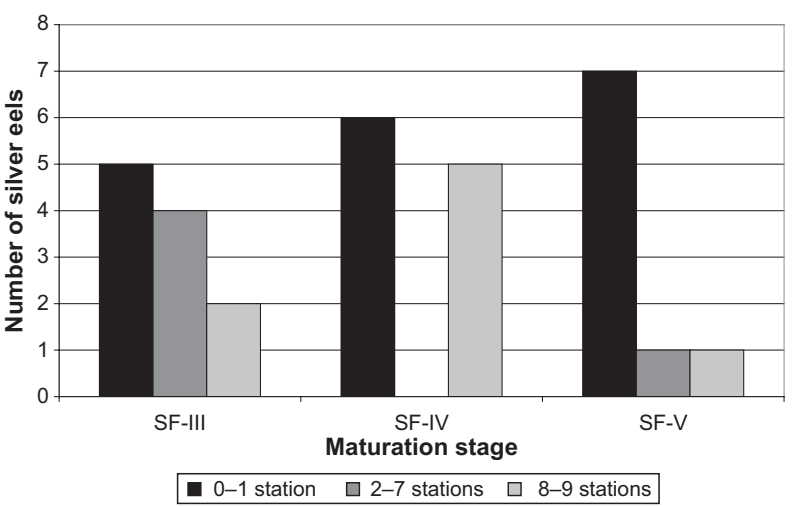

Fig. 3. Distribution of migration success for the maturation stages SF-III to SF-V, according to Durif et al. (2005). Migration success is expressed as the number of silver eels of different maturation stages detected at successive detection stations (numbered as in Fig. 1), that is Stations $0-1=$ silver eels not detected or only at station 1 (nonmigrants); Stations $2-7=$ silver eels migrating between 22.5 and $228 \mathrm{~km}$; Stations $8-9=$ silver eels migrating $>228 \mathrm{~km}$.

far as the estuary in synchrony with naturally recruited female silver eels. Eels used in our experiment were caught at four different locations, two of them (Canal Bocholt-Herentals and Canal Brussel-Charleroi) outside the Meuse catchment. Apart from potential bias in stocked eels because of absence of imprinting, also sudden changes in water quality (such as increased turbidity or decreased conductivity) during translocation between sampling and release sites might induce locomotory activity as described by Durif et al. (2008).

The data gained in this study confirmed the reliability of this telemetry system as reported in earlier work (e.g., Winter et al. 2006; Breukelaar et al. 2009), and the method is proven useful to track the route and to study some biological features (e.g., speed and timing) of the silver eel migration in the River Meuse. Quality check of the regular functioning of the detection stations consisted of an automatic check every $12 \mathrm{~h}$ at all stations. The transponders and telemetry devices used in this study allowed for an efficient detection of tagged eels passing at the detection stations. Eels detected at stations positioned on the lower reaches of the river were detected at the upstream stations. Unlike in the River Rhine where during similar work Breukelaar et al. (2009) reported nondetection problems because of limited system performance at a few stations during conditions of very high water flow, these problems were not experienced during our study.

\section{Conclusion}

The EU recovery plan (EU, 2007) has set a silver eel escapement goal at $40 \%$ of the historic biomass production. In the case of the Belgian part of the 


\section{Verbiest et al.}

Meuse eel management unit, this goal amounts to 21.2 tons of silver eel escapement, which is currently not met (Belpaire et al. 2010). This study suggests that eels from the transboundary Meuse have an escapement rate of approximately $15 \%$ and presumably HPS and fisheries within the Meuse delta are causing losses to silver eels during their downstream migration. Hence, reductions in the mortality of migrating silver eels are urgently needed to meet the escapement goals.

We are aware that because of the rather limited number of individuals used in this study, one has to be very careful when extrapolating these results. Nonetheless, this study has demonstrated that telemetry with fixed detection stations along a river is a valuable technique to study eel migration in River Meuse. We recommend that such a technique is combined with manual tracking techniques to estimate the number and behaviour of nonmigrants. Apparently, current methods to estimate maturity of silver eels do not adequately reflect their ability to initiate migration. More information is needed on why some tagged putative silver eels do not start their migration or cease migration during their journey. Another further focus is to evaluate the exact causes of mortality of 'lost migrants'. Large-scale studies on the silver eel migration in River Meuse are essential for the proposed restoration measures and the future management of the eel within the Meuse basin eel management plan.

\section{Acknowledgements}

The authors wish to thank the field workers who contributed in the eel assessments and Y. Maes for the cartography. RWS is acknowledged for financing the detection infrastructure in the Netherlands, INBO for financing the detection infrastructure in Belgium. We acknowledge SETHY (Belgian data available free of charge by the Public Service of Wallonia (SPW), Mobility and Operational Branch Waterways, Department of Management integrated hydrological, Hydrological Serviced'Etudes, SETHY) and Waterbase (Rijkswaterstaat, the Netherlands) for use of the water condition data. We also wish to thank three anonymous referees for helpful and constructive comments.

\section{References}

Aarestrup, K., Økland, F., Hansen, M.M., Righton, D., Gargan, P., Castonguay, M., Bernatchez, L., Howey, P., Sparholt, H., Pedersen, M.I. \& McKinley, R.S. 2009. Oceanic spawning migration of the European eel (Anguilla anguilla). Science 325: 1660 .

Aarestrup, K., Thorstad, E.B., Koed, A., Svendsen, J.C., Jepsen, N., Pedersen, M.I. \& Økland, F. 2010. Survival and progression rates of large European silver eel Anguilla anguilla in late freshwater and early marine phases. Aquatic Biology 9: 263-270.

Acou, A., Feunteun, E., Laffaille, P. \& Legault, A. 2000. Catadromous migration dynamics of European eel (Angu- illa anguilla, L.) in a dammed catchment. Verhandlungen des Internationalen Vereinigung Limnologie 27: 31173120 .

Acou, A., Laffaille, P., Legault, A. \& Feunteun, E. 2008. Migration pattern of silver eel (Anguilla anguilla, L.) in an obstructed river system. Ecology of Freshwater Fish 17: 432442.

Acou, A., Gabriel, G., Laffaille, P. \& Feunteun, E. 2009. Differential production and condition indices of premigrant eels (Anguilla anguilla) in two small Atlantic coastal catchments of France. In: Casselman, J. \& Cairns, D., eds Eels at the edge, Symposium 58. Bethesda, MD: American Fisheries Society Symposium 58: 157-174.

Belpaire, C., Goemans, G., Geeraerts, C., Quataert, P. \& Parmentier, K. 2009. Decreasing eel stocks: survival of the fattest? Ecology of Freshwater Fish 18: 197-214.

Belpaire, C., Buysse, D., Coeck, J., Geeraerts, C., Ovidio, M., Philippart, J.-C., Reyns, T., Stevens, M., Van Thuyne, G., Vlietinck, K. \& Verreycken, H. 2010. Report on the eel stock and fishery in Belgium 2009/'10. Report of the 2010 session of the Joint EIFAC/ICES Working Group on Eels. Hamburg, Germany, from 9 to 14 September 2010. EIFAC Occasional Paper 41. ICES CM 2010/ACOM: 18. Rome, FAO/Copenhagen, ICES. 2010. 721 pp.

Breukelaar, A.W., bij de Vaate, A. \& Fockens, K.T.W. 1998. Inland migration study of sea trout (Salmo trutta) into the River Rhine and Meuse (Netherlands), based on inductive coupling radio telemetry. Hydrobiologia 371/372: 29-33.

Breukelaar, A.W., Ingendahl, D., Vriese, F.T., De Laak, G., Staas, S. \& Klein Breteler, J.G.P. 2009. Route choices, migration speeds and daily migration activity of European silver eel, Anguilla anguilla in the River Rhine, north-west Europe. Journal of Fish Biology 74: 2139-2157.

Cullen, P. \& McCarthy, T.K. 2003. Hydrometric and meteorological factors affecting the seaward migration of silver eels (Anguilla anguilla, L.) in the lower River Shannon. Environmental Biology of Fishes 67: 349-357.

Davidsen, J.G., Finstad, B., Økland, F., Thorstad, E.B., Mo, T.A. \& Rikardsen, A.H. 2011. Early marine migration of European silver eel Anguilla anguilla in northern Norway. Journal of Fish Biology 78: 1390-1404.

De Leeuw, J.J. \& Winter, H.V. 2008. Migration of reophilic fish in the large lowland rivers Meuse and Rhine, the Netherlands. Fisheries Management and Ecology 15: 409415.

Dekker, W. 2000. Impact of yellow eel exploitation on spawner production in Lake IJselmeer, The Netherlands. Dana 12: 2540.

Dekker, W. 2004. Slipping through our hands: population dynamics of the European eel. PhD thesis, University of Amsterdam, The Netherlands, 188 pp.

Durif, C.M.F. \& Elie, P. 2008. Predicting downstream migration of silver eels in a large river catchment based on commercial fishery data. Fisheries Management and Ecology 15: 127-137.

Durif, C., Elie, P., Gosset, C., Rives, J. \& Travade, F. 2003. Behavioural study of downstream migrating eels by radio telemetry at a hydroelectric power plant. In: Dixion, D.A., ed. Biology, management and protection of catadromous eels, Symposium 33. Bethesda, MD, USA: American Fisheries Society, pp. 343-356. 
Durif, C., Dufour, S. \& Elie, P. 2005. The silvering process of Anguilla anguilla: a new classification from the yellow resident to the silver migrating stage. Journal of Fish Biology 66: 1025-1043.

Durif, C., Dufour, S. \& Elie, P. 2006. Impact of silvering stage, age, body size and condition on reproductive potential of the European eel. Marine Ecology Progress Series 327: 171-181.

Durif, C.M.F., Travade, F., Rives, J., Elie, P. \& Gosset, C. 2008. Relationship between locomotor activity, environmental factors, and timing of the spawning migration in the European eel, Anguilla anguilla. Aquatic Living Resources 21: $163-170$.

EU 2007. Establishing measures for the recovery of the stock of European eel. Council regulation (EC) No 1100/207 of 18 September 2007. Official Journal of the European Union L 248: 17-23.

Feunteun, E. 2002. Management and restoration of European eel population (Anguilla anguilla): an impossible bargain. Ecological Engineering 18: 575-591.

Feunteun, E., Acou, A., Laffaille, P. \& Legault, A. 2000. European eel (Anguilla anguilla): prediction of spawner escapement from continental population parameters. Canadian Journal of Fisheries and Aquatic Sciences 57: 16271635 .

Geeraerts, G. \& Belpaire, C. 2010. A review of the effects of contaminants on European eel. Ecotoxicology 19: 239-266.

Geeraerts, C., Focant, J.-F., Eppe, G., De Pauw, E. \& Belpaire, C. 2011. Reproduction of European eel jeopardised by high levels of dioxins and dioxin-like PCBs? Science of the Total Environment 409: 4039-4047.

HIC 2009. Hydrologisch Informatiecentrum. Waterbouwkundig Laboratorium, Departement Mobiliteit en Openbare Werken, Vlaamse Overheid. Available at: http://www.water standen.be/.

Jansen, H.M., Winter, H.V., Bruijs, M.C. \& Polman, H.J.G. 2007. Just go with the flow? Route selection and mortality during downstream migration of silver eels in relation to river discharge. ICES Journal of Marine Science 64: 1437-1443.

Jepsen, N., Schreck, J., Clements, C. \& Thorstad, E.B. 2003. A brief discussion on the $2 \% \mathrm{tag}$ /bodymass rule of thumb. In: Spedicato, M.T., Lembo, G. \& Marmulla, G. eds. Aquatic telemetry: advances and applications. Proceedings of the Fifth Conference on Fish Telemetry held in Europe. Ustica, Italy, 9-13 June 2003. Rome, FAO/COISPA. 2005. 295 pp.

Klein Breteler, J., Vriese, T., Borcherding, J., Breukelaar, A., Jörgensen, L., Staas, S., de Laak, G. \& Ingendahl, D. 2007. Assessment of population size and migration routes of silver eel in the River Rhine based on a 2-year combined mark- recapture and telemetry study. ICES Journal of Marine Science 64: 1450-1456.

Knights, B. 2003. A review of the possible impacts of longterm oceanic and climate changes and fishing mortality on recruitment of anguillid eels of the Northern Hemisphere. Science of the Total Environment 310: 237-244.

Lowe, R.H. 1952. The influence of light and other factors on the seaward migration of the silver eel (Anguilla anguilla L.). Journal of Animal Ecology 21: 275-309.

McCleave, J.D. \& Arnold, G.P. 1999. Movements of yellowand silver-phase European eels (Anguilla anguilla L.) tracked in the western North Sea. ICES Journal of Marine Science 56: 510-536.

Okamura, A., Yamada, Y., Tanaka, S., Horie, N., Utoh, T., Mikawa, N., Akazawa, A. \& Oka, H.P. 2002. Atmospheric depression as the final trigger for the seaward migration of the Japanese eel Anguilla japonica. Marine Ecology Progress Series 234: 281-288.

Tesch, F.W. 1974. Speed and direction of silver and yellow eels, Anguilla anguilla, released and tracked in the open North Sea. Berichte der Deutschen wissenschaftlichen Kommission für Meeresforschung 23: 181-197.

Tesch, F.W. 2003. The eel. Oxford, UK, Blackwell Science Ltd. 408 pp.

van den Thillart, G., van Ginneken, V., Körner, F., Heijmans, R., van der Linden, R. \& Gluvers, A. 2004. Endurance swimming of European eel. Journal of Fish Biology 65: 312318.

Verreault, G., Dumont, P., Dussureault, J. \& Tardif, R. 2010. First record of migrating silver American eels (Anguilla rostrata) in the St. Lawrence Estuary originating from a stocking program. Journal of Great Lakes Research 36: 794797.

Vøllestad, L.A., Jonsson, B., Hvidsten, N.A., Naesje, T.F., Haraldstad, Ø. \& Ruud-Hansen, J. 1986. Environmental factors regulating the seaward migration of European silver eels (Anguilla anguilla). Canadian Journal of Fisheries and Aquatic Sciences 43: 1909-1916.

Westerberg, H., Lagenfelt, I. \& Svedäng, H. 2006. Silver eel migration behaviour in the Baltic. International Council for the Exploration of the Sea, ICES C.M. 2006/J:26, $14 \mathrm{pp}$.

Westin, L. 2003. Migration failure in stocked eels Anguilla anguilla. Marine Ecology Progress Series 254: 307-311.

Winter, H.V., Jansen, H.M. \& Bruijs, M.C. 2006. Assessing the impact of hydropower and fisheries on downstream migrating silver eel, Anguilla anguilla, by telemetry in the River Meuse. Ecology of Freshwater Fish 15: 221-228. 